\title{
THE STRATEGIES OF WOMEN PROTECTION IN SOLVING DOMESTIC VIOLENCE CASES IN CENTRAL JAVA THROUGH SHELTERED HOUSE
}

\author{
Suteki and Ani Purwanti*) \\ Faculty of Law Diponegoro University Semarang, Indonesia \\ ani_purwanti81@yahoo.com
}

\begin{abstract}
Domestic Violence is a highly occured violence which is pervasively victimizing women. Several study show that in the handling process, women, as the victim of domestic violence, has difficulty to go back home, which means she is going to face tortures again by her husband in her house. The problems are: the protection of women in eradicating Domestic Violence in Central Java and; and the ideal protection for women in solving Domestic Violence through Sheltered house. this research uses Socio-Legal method. The existence of sheltered house can become the alternative to protect the victimized women and handle the domestic violence whether in the family sphere or in the public sphere.The increasing number of women as the victim of violence time by time is spreading to the small city but based on the data of 35 regencies and cities in Central Java, only 7 areas which have sheltered house.
\end{abstract}

Keywords: Sheltered House, Domestic Violence, Central Java

\section{Introduction}

Domestic violence is an interesting social phenomenon to be examined. This phenomenon happens with several supports from the other complex social orders, like socio-religious moral, cultural perspectives, economic background, ideology, and the supporting law system. Later, these social orders oftenly cause the practice of domestic violences.

Generally, domestic violence alwas involves several parties in a family, whether husband, wife, children, domestic workers (housemaid), or the other family members. But, from all of those parties, domestic violence mostly occurs 
based on patriarchal principle, so, men always become the offenders of the violences and women always become the victims. In the context of violence against women, this violence has been considered globally as the violation of women's basic rights.

Domestic violence, which mostly victimizes women, starts from the range of verbal abuse, physical abuse, until the violation of basic rights of the women. Then, The Convention of Discrimination Against Women, as the international instrument of women's rights protection says that such violences, intimidation, and fears becomes the obstacle of women to actively participate in society's activity.

There have been many academician formulated the concept of violences, but, generally, the conception of violences can be formulated with the indication of misuse of power, inequality, and domination of certain party to another party ${ }^{151}$. The misuse of power is done to force even lie to other people that costs the integrity and trust from the people who becomes the victims of the misuse of power. The misuse of power oftenly occurs because the existence of inequal status whether to every individual or groups or nations.

Based on the perspective of law, the problem of domestic violences has been involved in public debate since the age of 1800, where the debate is in the scope of dividing public sphere and private sphere with non-intervention principle in private sphere $^{152}$. The private-sphere is considered tend to be natural, free, and neglected. Therefore, this perception cause over-freedom which ease the potencies of violence in the sphere.

The segmentation of private sphere and public sphere affects the position of women. Private sphere is considered as the maximum scope for women, while the public sphere is mostly acquired by men. Nevertheless, men also have full control in their private sphere. This thing creates subordinate position of women to men,

${ }^{151}$ R. Valentina Saragih \& Ellin Rozana, Pergulatan Feminisme and HAM, (Bandung: Insitut Perempuan. 2007), p.73

152 See, Carol Pateman, Feminst Critiques of The Public/Private Dichotomy: The Disorder of Women, In Hilaire Barnett (ed)., Sourcebook On feminist Juristprudence, (London \& Sydney: Cavendish Publishing Limited, 1996), p.143. 
so, women is mostly considered as inferior to men's position. This women's inferiority has been generally imprinted to the society which is supported with several legitimacy, starting from philosophy, religious doctrine, until the positive law itself.

This structure of power has been historically occurred and become the common situation of the society. Thus, the violences easily occurs to women. Therefore, it can be understood that violence against women is the manifestation of inequal power of men to women which is led by the domination and discrimination against them preventing them to develop their potential completely in the society.

In Indonesia, actually, there has been a ground-norm which copes the concept of humanism, where it has been contained in the second moral principle of Pancasila as "Kemanusiaan yang adil and Beradab (Just and Civilized Humanity)". So, the basic ideology of the nation and its constitutions has formulated the concepts regarding appreciating human rights equally for men and women before the law. As what has been stated in the Article 27 number (1) of 1945 Consitution of Indonesia.

"Every citizen has equal position before the law and governance and responsible to uphold law and governance with no exception"

According to the article and the ratification of Convention on the Elimination all form Diskrimination Against Woman (CEDAW) after considered as in line with Pancasila or 1945 Consitution of Indonesia which is constituted as Act Number 7 year 1984 regarding CEDAW Ratification, Indonesia should be actively involved in achieving gender equality.

In reality, women are still in the subordinate position and discriminated whether politically or as the subject of law, so, in the context of this discussion there should be a focus in discussing women as the victim of violences in the context of domestic violence or private sphere. As the turning movement, in 1979, 
there was a declaration of eradication of discrimination against women where Indonesia was also ratified it in Act number 7 year $1984^{153}$.

Somehow, during the implementation of the Act, the violences and injustices against women are continuously occuring. This statement is proven by the Annual Reports of Comission of Violence against Women saying that the violences against women in post-reformation era are increased every year. Whereas, the urgency related to Domestic Violences is enshrined in item 23 Recommendation Number 19 year 1992 about violences against women saying that:

"Domestic Violence is the most dangerous form of violence to women. This thing is pervasively occurred in the society. In family-sphere, women in every ages become the target of violences, starting from thrashing, rapes, other forms of sexual attack, mental abuse and other forms of violences which is absolutely conditioned by traditional behavior. Economic dependency forces women to stay in the relation based on violences. The abolition of family responsibility by men is included as the violence or force. It also places women in the risks of health and forces, and eliminate the chance of participation in family life and public life based on the principle of equality" 154

In the Book of Law, violence against women is listed in Article 285, 286, 287, 288, and 297 categorized as crimes of decency ${ }^{155}$. But, the definition of violence as listed in the definition of Article 89 of the Book of Law only copes narrow scope based on physical abuse only. Meanwhile, psychological, economic, and sexual crimes against women can be found in the new Act of Act number 23 year 2004 regarding Domestic Violence Rules.

Several institution accommodates the interests of women, like National Comission of Women, LRC-KJ HAM (Legal Resources Center of Gender Equality

${ }^{153}$ It can be seen that Indonesia has not yet determined whoheartedly to ratify CEDAW. Valantina Saragih sees this from the reservation of Article 29 number (1) of CEDAW ratification in Act number 7 year 1984. This reservation signals the unreadiness of the country in upholding the women's rights, see further in, Ibid, p. 71.

${ }^{154}$ Directorate General of Human Rights of the Ministry of Law and Human Rights. The Guidance of Human Rights Fulfillment. 2011 p. 258

155 "Therefore, the crimes of decency which cause injury or related to women's vital organ is not only categorized as crimes of decency" Op Cit Niken Savitri .p.68 
and Human Rights), etc. also has released several data, information, and literatures about the violence against women all this time. According to those data, it can be seen that violence againt women is based on several things, starting from economic profession, economic condition, infidelity, and other related problems. But, generally, the focus of violence against women is how the total of cases and the reporting of cases to women is increased year by year and the types of violences against women.

\section{Research Methods}

The focus of this study is finding the model of protection to women in the attempt of eradicating domestic violence in Central Java through sheltered house. So, the approach method of the research was using empirical juridical approach based on primary and secondary data (formed as legal law and the field data from the related stakeholders of handling violences against women.

\section{Result and Discussion}

The General Description of total of women as the victim of violence in 2013 which is reported by National Comission of Women, and released at $7^{\text {th }}$ March 2014 in Jakarta:

Figure 1. Domestic Violence Graphic 2013

\section{DOMESTIC VIOLENCE'S GRAPHIC 2013}

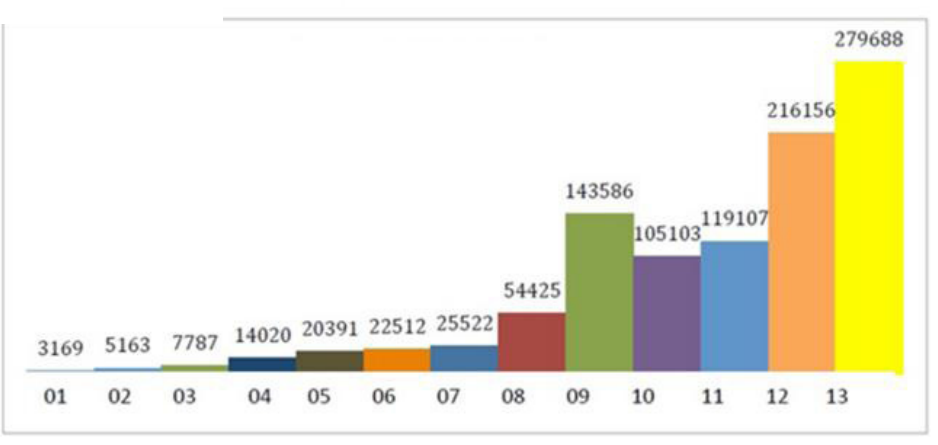


Data of Victim of Violence against Women in 2013 released by National Comission of Women in 2014

According to National Comission of Women, this $94 \%$ data of CATAHU in 2013 is based on the cases/matters handled by Religion Court in which there were 263.285 cases. The other $6 \%$ - 16.403 cases of Violence Against Women from service provider partner institution were responded by turning back the form of data collection of National Comission of Women (there were 195 service provider partner institution). These data is similar to the previous year and it can be said that this number is an iceberg, it means there were many women as the victim which were not able and brave to share their experience, even breve to come to the service provider to ask for help. This reluctance and incapability is merely caused by the existing stigma in the society where women as the victim of violence is considered as the offender, 'prostitute' or simply does not have a good behavior, so, they deserve the violence they have experienced ${ }^{156}$.

The minimum total of reporting of violences against women from the data is not representing the reality occurring in the society. This thing is because of the violence among the society is placed on the widest and most based on the criminal statistic method. The reported violences is placed in the deepest part, so, the data released by every institution are not merely representing overall total of violences against women.

The data of National Comission of Women regarding the types of domestic violence in the period of 2013 until the initial period of 2014 can be seen as follow:

\footnotetext{
156 The Annual Report of Violence Against Women in 2013: Kegentingan Kekerasan Seksual: Lemahnya Upaya Negara, (Jakarta: Komnas Perempuan, 2014), page. 19 (pdf), accesed in the link: $\quad$ Http://Www.Komnasperempuan.Or.Id/Wp-Content/Uploads/2014/11/CATAHU-2014KEGENTINGAN-KEKERASAN-SEKSUAL-LEMAHNYA-UPAYA-PENANGANANNEGARA.Pdf (Thursday, $22^{\text {nd }}$ January 2014, At 18.30 WIB)
} 
Figure 2. Domestic Violence

\section{Domestic Violence}

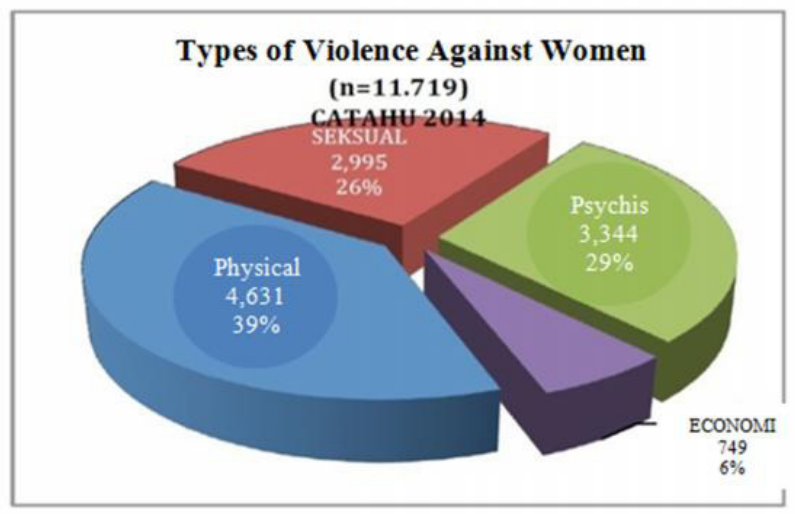

The Data of Violence against Women in 2013 released by The National Comission of Women in 2014

According to the data, it can be seen that physical violence against women is still dominated. Comparing to the other forms of violences, physical violences is easily occurred in public-sphere/small community. It is because of the legal apparatus does not cope the private sphere. The reports of domestic violence or personal relation (DV/PR) in 2013- early 2014 reached 11.719 cases. From the total reports, the form of violences can be divided and displayed in the diagram. The forms of DV/PR includes: Violences Against Wives (VAW, 64\%), Violence in Dating (VID, 21\%), Violences Against Daughter (VAD, 7\%), Violence from exHusband (VFeH,1\%), Violence from ex-Boyfriend (VfeB, 1\%), and Violence against Housemaid (VAH, 23 cases) ${ }^{157}$.

157 Ibid, p.24 
Figure 3. The Data of Victim of Violence Against Women 2014

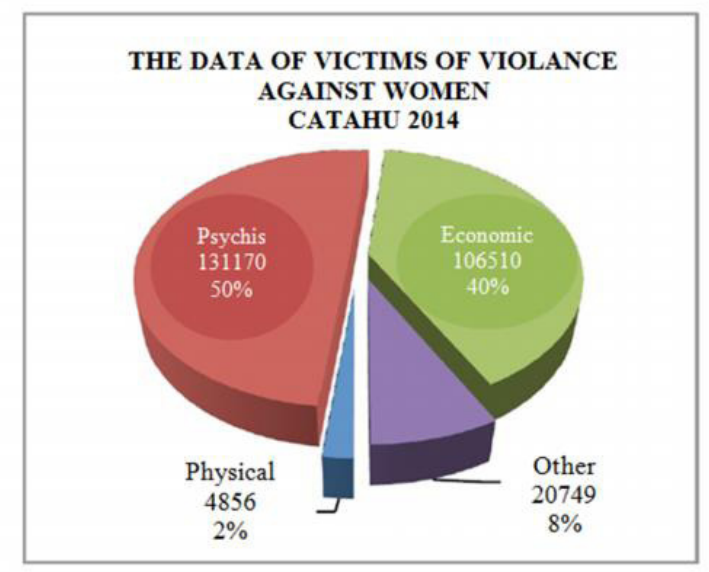

The Data of Victims of Violence against Women in 2013 released by National Comission of Women in 2014

The form of phsycic violence reaches the percentage of $50 \%$ includes: unfair polygyny, behavioral crisis, jealousy, forced marriage, underage marriage, mental abuse, punished, political, third-party disruption, and less-harmonious relation, while the economic violence (40\%) copes economic problems and irresponsible acts. Physical abuse (2\%) includes physical cruelty and biological disability. According to the data of Religion Court the data of sexual abuse cannot be released. Nevertheless, several categories can be included into sexual abuse, such as inharmonious relation, forced marriage, underage marriage, unfair polygyny, $\operatorname{etc}^{158}$.

Through the documentation of the violence data, the government should be attempted to anticipate the increasing number of Domestic Violences' victims.

158 Ibid, p. 23. 
Besides, the Government should oversee the court process, so, the victim of Domestic Violence can get the justice system they deserve. The government should also protect and assist the victim in a sheltered housing.

The sheltered housing or also called as protection house is a temporary living place for women and children as the victim of violences. This house provides protection, welfare, and helps so the victim can be spared from further violence and able to solve the problem. Ususally, in facing domestic violence, the victims is brought to this sheltered house because the victim feels threatened in their house that they need a protective house.

In the sheltered house, the victim of domestic violence can create a community sharing activity to understand each invidual in seeing the problem of domestic violence. So, by this sheltered house, the residents can give a positive effect to other residents after having post-traumatic condition of domestic violence. Even if the sheltered house has been initiated in several area, but, the implementation is still low. In Article 17 Number 23 year 2004 regarding the Eradication of Violence against Women is explained that in providing temporary protection, the police can cooperate with health workers, social workers, assisting volunteers, or religious figure to assist the victim. Therefore, the creation of sheltered house should be completely assisted by the Government with the support of independent institution in every area.

\subsection{The Data of Sheltered House in Central Java}

From 35 Regency/City in Central Java, there are 7 area which has Sheltered House. All of those houses are formed based on the decree of Regent or Mayor. The list can be seen in the following data:

a. Grobongan Regency with Decree of Regent of SK Bupati number 260/884/IV/2006 renewed every three year: 202.85/228/2013.

b. Kendal Regency with Decree of Regent of SK Bupati number 463/248/2012, budget in $2015: 380$ million rupiahs.

c. Pekalongan City with Decree of Mayor of SK Walikota number 411.2/110 tahun 
2009, budget in $2015: 191$ million rupiahs.

d. Surakarta City with Decree of Mayor of SK Walikota number 462.05/84A/I/2010 and Memorandum of Understanding Number 463/2.604.1, budget :136 million rupiahs.

e. Sragen Regency with Decree of Regent of SK Bupati number 260/36/002/2012 and Surat Keputusan Bupati number 188.4/418/002/2013 regarding the provision of RSUD dr.Soehadi Prijonegoro, Dr Soeratno and Puskesmas in Sragen Regency as the service provider of violence based on gender and against children in Sragen Regency, budget : 200 million.

f. Semarang City, SK Walikota Semarang Number : 463.05/112, $4^{\text {th }}$ May 2005 about the Creation of Integrated Service Team to Handle Gender-Based Violence Against Women and Children and renewed with the Decree No. 463/A.023, 12 $2^{\text {th }}$ February 2009 and renewed again in the Decree of Semarang Mayor in $6^{\text {th }}$ January 2011 No. 463/05/2011. Besides, the Decree of Society Empowerment, Women, and Family Planning of Smearang City Number : $061.1 / 282$ in $24^{\text {th }}$ January 2014 about the creation of Executing Team Permanent Secretariat the Integrated Service of Gender-based violence Against Women and Children

g. Wonosobo Regency with Regent Rule Perbub Number 14 and Number 15 year 2008 , budget in $2015: 40$ million rupiahs, in $2014: 30$ million rupiahs and in 2013 : 23 million.

\subsection{Shelter "Seruni" in Semarang City}

PPT SERUNI is an Integrated Service to Solve Gender-Based Violence against Women and Children in Semarang City, it is an abbreviation of Semarang Terpadu Rumah Perlindungan Untuk Membangun Nurani and Cinta Kasih Insani (an Integrated Sheltered Housing of Protection and Love of Humanity in Semarang). PPT seruni works in protecting and handling the victim of genderbased violence. The criteria of the victims are gender-based violence victim and trafficking especially for women and children which face one of violence forms 
whether physical abuse, sexual, psychological, social, and economic negligence. The priority of the service is given to women and children from poor, risky and marginal background in Semarang, and, with the consideration of humanity/rights can be accessed by woman and victims of violences out from Semarang, but the location of violences, the cases, witnesses, offenders, or victim is in Semarang, and the exception can be occurred to the other thing as long as it is not backclashing the principle of rights fulfillment.

PPT SERUNI was born in $1^{\text {st }}$ March 2005 as the result of agreement between the Training and Cross-Sectoral Coordination which was held by TOT Team of Rights Education Based on Gender Perspective in Central Java cooperating with National Comission of Anti Violence against Women (KOMNAS PEREMPUAN), which was visited by the representative of Government, Academician, LSM, Women Practitioners and Activist. Thereby, PPT Seruni is created in Semarang City, which later was supported and controlled by the Government of Semarang City by the Decree of Semarang Mayor Number: 463.05/112, $4^{\text {th }}$ May 2005 regarding the creation of of Executing Team of Service Provider of the Integrated Service of Gender-based violence Against Women and Children "SERUNI" Kota Semarang, and confirmed by the Mayor of Semarang in $20^{\text {th }}$ May 2005 in the National Awakening Day. In 2009, the Decree is renewed since there were many team members retired, so, the Decree of Mayor regarding the creation of of Executing Team of Service Provider of the Integrated Service of Gender-based violence Against Women and Children "SERUNI" of Semarang City is changed with Decree No. 463/A.023, $12^{\text {th }}$ February 2009. In 2011, the Decree of Mayor regarding the creation of of Executing Team of Service Provider of the Integrated Service of Gender-based violence Against Women and Children "SERUNI" had been changed into Decree of Semarang Mayor in $6^{\text {th }}$ January 2011 No. 463/05/2011. From the Decree of Mayor, the Provision of Society, Women, and Family Planning Empowerment of Semarang City Number: 061.1/282, 24 ${ }^{\text {th }}$ January 2014 about the creation of Executing Team Permanent Secretariat the Integrated Service of Gender-based violence Against Women and Children in Semarang City 
was made where every budgeting will be based on the city's budget and the other funding sources is legal but not bonded.

\subsection{The Protection of Women as the Victim of Domestic Violence in Boyolali Regency}

The protection of women as the victim of violence in public or domestic is regulated in the Local Regulation of Boyolali Regency Number 14 Year 2013 about Children's Protection. The regulation is used specifically for children's protection, so, the women's protection is not exist. Thus, there are still many cases of violence against women since the Government of Boyolali regency does not have Local Rule specifically protect and handle violence againt women whether in domestic or public. It can also be said that there has not been any Specififc regulation from the Local Government to handle Domestic Violence in the form of Local Regulation or Decree of the Regent. For the children, there is Local Regulation of Boyolali Regency Number 14 Year 2013 regarding Children's Protection. Even if there is no any specific rule to protect women, Boyolali's government has created Integrated Empowerment of Women and Children's Central Team of Boyolali Regency under the coverage of Women Empowerment, Children's Protection, and Family Planning of Boyolali Regency. In this place there is no any sheltered housing as the place to protect and handle the cases of violence against women in the public or domestic.

If there is a case of domestic violence to women in in the public or domestic, the police will take a responsibility as the law enforcer to the offender in the form of diplomatic approach. In everyday patrols, the police always coordinate with the Integrated Empowerment of Women and Children's Central Team of Boyolali's regency and with the active non-governmental organization related to domestic violence and protection for women and children which si through the NGO of Women Care Forum of Boyolali ( FPPB ). 


\section{Conclusion}

The regulation related to protection of women as the victim of violence started from the 1945 Consitution of Indonesia, Act Number 7 year 1984 about CEDAW ratification, Act Number 39 year 1999 about Human Rights, specifically to Act Number 23 year 2004 about the Eradication of Domestic Violence, and Protection of Witness and Victim Act. In Central Java, the regulation of sheltered house comes through Local Regulation or through the Decree of Regent or Mayor and SOP regarding the services to the victim of violence against women. From 35 regencies and cities in Central Java, there are only 7 sheltered house in Grobogan, Kendal, Pekalongan, Solo, Sragen, Kota Semarang and Wonosobo.

The form of sheltered house is an integrated homestay with one-stop services, where it integrates the protection, services, and handling for women as the victim of violence domestically or publicly. Thus, it also integrates the function of Police, Hospital, Psychologist, NGO, Religious figure, and Public figure, so, the women as the victim of violence can feel safe and guaranteed that the cases they face will be over.

There should be a concern from the government (Regent/Mayor) regarding the importance of sheltered house for women as the victim of violence in public or domestic, so, the occurring cases of domestic violence can be solve in onestopservices in the sheltered house based on the standard operational procedures. The concerns should be formed as the Regulation or Decree of Regent/Mayor which becomes the background of Sheltered House.

The society, religious figure, and public figure should urge the Local Government to create an integrated ideal sheltered which is going to solve and handle women as the victim of domestic or public violence.

\section{References}

Irianto, Sulistyowati. (2006). Memperkenalkan Studi Sosiolegal. Bandung: Buku Obor.

Kusuma, Candra. (2013). Penelitian Interdisipliner Tentang Hukum. Jakarta: Epistema Institute. 
Pateman' Carol. (1996). Feminst Critiques of The Public/Private Dichotomy: The Disorder of Women, Dalam Hilaire Barnett (ed)., Sourcebook On feminist Juristprudence. London \& Sydney: Cavendish Publishing Limited.

Rahardjo, Satjipto. (2006). Ilmu Hukum. Bandung: Citra Aditya Bakti. (2006). Hukum dalam Jagat Ketertiban. Jakarta: UKI Press.

Saragih, R. Valentina \& Ellin Rozana. (2007). Pergulatan Feminisme and HAM. Bandung: Insitut Perempuan.

Direktorat Jenderal Hak Asasi Manusia Kementerian Hukum and Hak Asasi Manusia. (2011). Pedoman Pemenuhan Hak Asasi Manusia.

http://www.komnasperempuan.or.id/wp-content/uploads/2014/11/CATAHU-2014KEGENTINGAN-KEKERASAN-SEKSUAL-LEMAHNYA-UPAYAPENANGANAN-NEGARA.pdf (Thursday, 22 ${ }^{\text {nd }}$ January 2014, at 18.30 WIB).

Government Act

Act Number 7 Year 1984 about CEDAW Ratification

Act Number 39 Year 1999 about Human Rights

Act Number 23 Year 2004 about The Eradication of Domestic Violence

Act Number 13 Year 2006 about Victim and Witnesses Protection 